\title{
POLITICAL PARTY BALANCED SCORECARD CONCEPT FOR ANALYSIS OF THE PERFORMANCE MANAGEMENT OF THE ACTIVITY OF POLITICAL PARTIES IN ROMANIA
}

https://doi.org/10.47743/jopafl-2021-22-20

\author{
Ecaterina Cornelia UNGUREANU \\ Faculty of Economics and Business Administration, Dunarea de Jos University \\ Galati, Romania \\ corneliaungureanu13@gmail.com \\ Liliana Mihaela MOGA \\ Faculty of Economics and Business Administration, Dunarea de Jos University \\ Galati, Romania \\ liliana.moga@gmail.com

\section{Dragoș Sebastian CRISTEA} \\ Faculty of Economics and Business Administration, Dunarea de Jos University \\ Galati, Romania \\ dragoscristea@yahoo.com \\ Andi MIHALACHE \\ Faculty of Economics and Business Administration, Dunarea de Jos University \\ Galati, Romania \\ andys972@yahoo.com
}

\begin{abstract}
In the current international context in which political parties are going through a period of widespread and substantial erosion, the achievement of performance is a sine qua non condition for their existence and continuity on the political stage. The research is a case study on the analysis of the performance of a political party in Romania, at the end of 2019, using the strategic performance measurement model Balanced Scorecard, customized to the specifics of a political organization. A review of the existing international scientific literature and case studies was carried out to define a balanced plan of performance indicators in order to evaluate the activity of a political party. The paper realizes a personalization of the strategic model for measuring the performance of Balanced Scorecard through a computer application BSC Designer Light whose architecture is based on this managerial tool. The purpose of the scientific approach is to quantify the result of the analyzed party in a score obtained for the financial and parliamentary perspective of the proposed model and for each indicator / sub-indicator related to each perspective, as well as finding a final score of the party.
\end{abstract}

Keywords: political party, performance indicators, balanced scorecard, financial performance

\section{Introduction}

The sharp disintegration of traditional political relations, especially in Central and Eastern Europe, an area where political parties face great distrust of the electorate, due to the history of the undemocratic regime presided over by the communist party state and the 
transition to democracy, has favored the phenomenon of fragmentation of society and led to a profound individualization of political socialization processes. Currently, voter behavior is less conditioned by interest/influence groups, and technological development related to new forms of communication and political marketing, integrated with political management, have put Romanian political parties in front of an essential test on their ability to mobilize voters and perform in business.

\section{Literature review}

Amid the economic and financial crisis of 2008, civic responsibility has increased significantly, and researchers such as Radin, (2006) and Damgaard \& Lewis (2014), argue for the continuing need to measure the performance of public administration and governments due to society's skepticism about the performance of public institutions concern about spending public funds and allocating public resources. There is also a growing interest in measuring performance from the perspective of governments and political parties, due to increased international competition, targets for reducing budgets, and the need to increase the efficiency of public services.

In this context, political organizations propose an analysis of the stimuli related to the operational model of organizational innovation applied to political parties, proposed by Appleton and Ward (1997), focusing on "performance stimuli" as a need for innovation and organizational efficiency, and on the "periodic stimuli" associated with the various stages of a party's life cycle.

But what is the way to measure performance in the case of a political party?

A simplistic and pragmatic answer to this question, without being considered exhaustive, could refer to the modalities and tools of strategic management used to measure the performance of economic organizations. The challenges facing an economic organization in a market in which it operates can often be attributed to the challenges of the political scene, and the findings of a study by The Economist Intelligence Unit (2013) show that most companies face difficulties in formulating and implementing a strategy, the situation encountered and the case of political organizations. In addition, the research done by Mochiari (2016) presented the historical and forecasted evolution of the average life expectancy of a company, taking as reference the S\&P 500. Thus, studies showed that the average life expectancy of a large company in 2017 is 27 years old and anticipated the continuous reduction of this life to live until only 12 years, in 2027.

In this economic and socio-political environment with a higher degree of uncertainty and complexity than ever in recent decades, the application of a Strategic Management and Performance Measurement System adapted to political organizations can make the difference between the growth or disappearance of a political party. The middle ground, that of maintaining the status quo or organic growth, is no longer, in these conditions, a realistic option, at least for the time horizon of the next 5-10 years, for which the context presented is a motivation to analyze the opportunity to start implementing the Balanced Scorecard at the level of the activity of a political party. Adopted globally by nearly half of commercial companies and public sector organizations, the original Balanced Scorecard model has evolved to date into a solid and validated practice framework, used for integrated performance management in strategy execution. 
The adaptation and implementation of this tool on the model of the activity of a political organization can be the premises for the efficiency of the activity of the political entity. The reform of political parties as a phenomenon of political management requires the development of a system of performance indicators, applicable to the activity of political organizations in Romania, in order to evaluate the results of these entities. The multiple perspectives on the topic of political efficiency, have led to an evolution of the concepts of political performance, focusing on areas of interest, and most theories converge to define performance indicators set on different sectors: social, political and / or economic.

A relatively recent evolution of the notion of political performance includes Powell's (1982) approach that focused on three dimensions of political performance: citizen participation, government stability, and political order, while Putnam (1993) associated political performance with government efficiency by comparing the performance of several institutions, which resulted in a summary index - "Institutional Performance Index", designed based on 12 indicators related to institutions in the area of government influence. Lijphart (1999) had a broader approach, dividing the types of performance indicators into 3 major categories: the first group of performance indicators refers to macroeconomic management and violence control and consists of 19 macroeconomic indicators and 4 indicators of violence. (GDP deflator, consumer price index, unemployment, strike activity, budget deficits, riots and political deaths). The second set of performance indicators called quality of democracy contains 17 indicators, including Dahl's democracy rating, Vanhanen's democracy index, women's parliamentary representation, women's cabinet representation, Wilensky's rating on family policy, the rich-poor ratio, and turnout. The third set of indicators includes four different areas of social welfare, environmental protection, criminal justice and external aid and contains 10 indicators including: welfare state index, social spending, energy efficiency, the death penalty, external aid and defense aid.

Lane and Ersson (2000, 2202) also investigated political performance, and the result of the examination focused on 5 output indicators: central government revenues, general government consumption, central government deficits, social security and military spending, and 12 result indicators.

Roller's (2005) political efficiency model was condensed into a summary performance index - "General political efficiency", which initially analyzed 5 areas, of which the foreign policy one was abandoned, focusing in the end. 4 policy areas: internal security policy, economic policy, social policy and environmental policy. His study included a total of 14 efficiency indicators, some of which are related to economic policy, similar to the macroeconomic indices monitored by Lijphart (1999).

Starting from the classical model of a performance system, Högström (2011), classifies political performance, dividing it into two different major concepts, democratic performance and governmental performance associating democratic performance with the "entry" area of a political system, in while the governmental performance considers it afferent to the "exit" area of the political system, specifying at the same time a clear distinction between the two concepts. His model neglects the area of "processes" which, from the point of view of the approached topic is of maximum interest for the performance of a political party, focusing mainly on "results". In its sense, democratic performance addresses the levels of democracy and democratic norms, and governmental performance deals with the impartiality of institutions, the quality of bureaucracy, macroeconomic 
management. Högström (2011) also divides the concept of democratic performance into two sub-concepts; the level of democracy and the quality of democracy. The conceptual level of democracy refers to political rights, civil rights, and indicators that can be used to measure the level of democracy are indicators of democracy, such as those monitored by Freedom House (2018), and the quality of democracy refers to democratic norms, such as political participation, political competition and political equality.

Similarly divides the concept of government performance into two sub-concepts; government effectiveness and government quality. The classification of government effectiveness is based on the concept of political efficiency of Roller (2005) which includes: foreign policy performance, internal security policy performance, economic policy performance, social policy performance and environmental policy performance. The other secondary concept of government performance - the quality of government provides for the measurement of bureaucratic quality as well as impartiality in the exercise of public authority.

Starting from these theories, the present research aims to analyze the performance of a political party in Romania, at the end of 2019, using the strategic model for measuring performance, developed by Robert Kaplan and David Norton (1992, 1996) - Balanced Scorecard, customized to the specifics of a political organization. The summary of these researches on this topic, through the selection of the main indicators analyzed by specialists in management and political science, corroborated with the transposition of the Balanced Scorecard method into the political party activity, results in a multidimensional conceptual framework for quantifying the efficiency of a political party Political Party Balanced Scorecard.

The proposed model starts from the layering of Balanced Scorecard perspectives with Chiocchetti's (2016) approach, concerning the four components based on which the performance indicators of a political organization can be defined: electoral component, the participatory component, the parliamentary/governmental component and financial component. Their overlap with Högström's (2011) concept, which divides political performance into two different concepts, democratic performance and governmental performance, wich lead to an own interpretation of the Balanced Scorecard at the political organization level - Political Party Balanced Scorecard graphically presented according to figure 1. 
Figure 1. Political Party Balanced Scorecard adapted from Kaplan, R. and Norton, D.P.

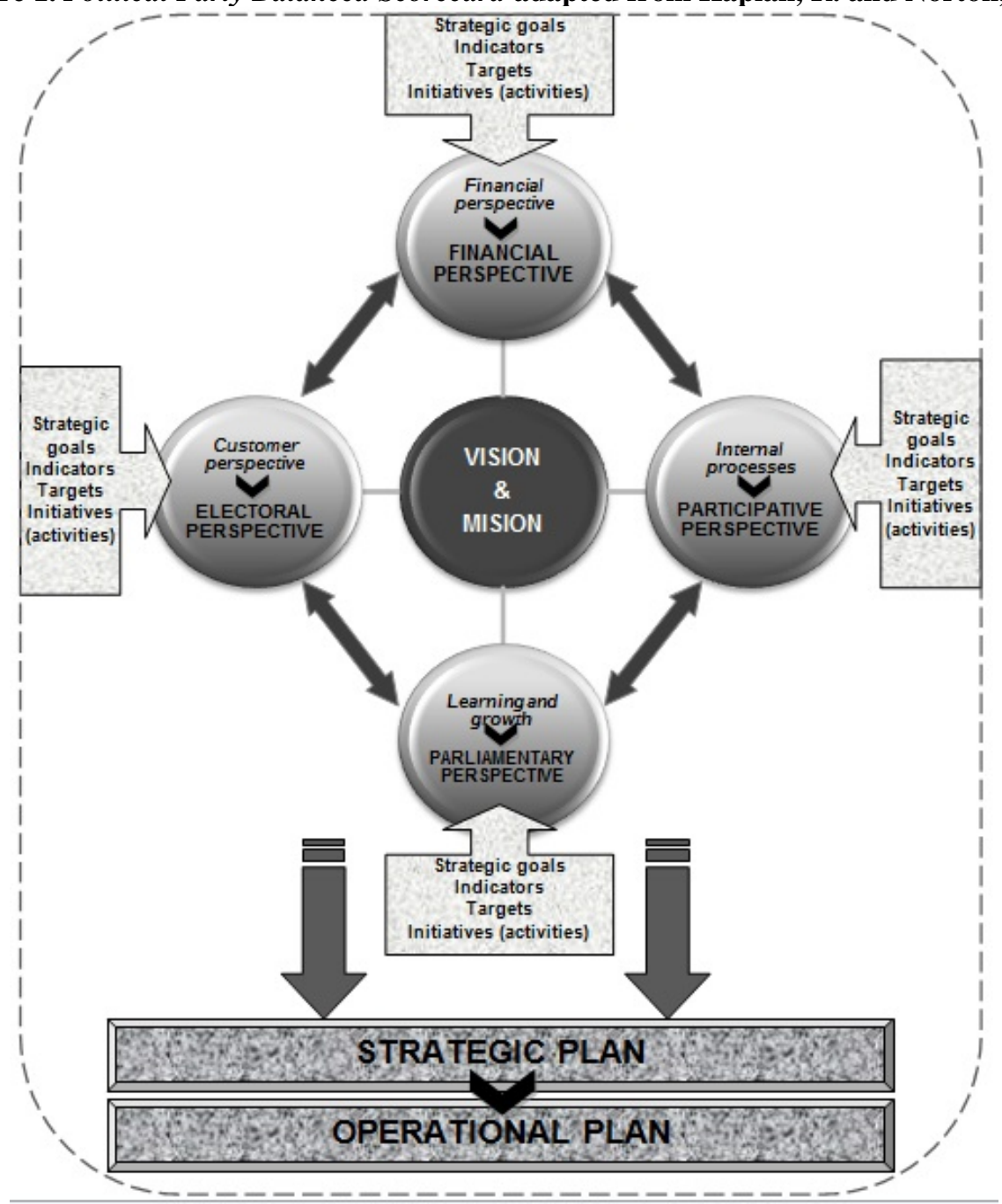

The customization mechanism of the Balanced Scorecard in the Political Party Balanced Scorecard for a Romanian political entity is similar to that for an economic organization since it pursues the same stages, starting with shaping the vision of the party and guidelines related to the strategic plan, continuing with establishing its own goals for each perspective, depending on which there should be indicators certain specific to that goal and which to define it in the most direct manner possible. Subsequently, based on historical data, if available, there are defined those parameters, those values, targets of each indicator, whose interpretation expresses the status/degree of achieving the goal. Of a particular importance is also the component actions of the operational plan, the activities currently undertaken by the party, of which implementation depends directly the degree of reaching the set operational objective, which is why monitoring the execution of operational plans should be a priority for the members responsible of the organization.

Adapting the instrument to the distinctiveness of the activity of a political party consists in the customization of all the component elements from the perspectives, strategic plan, indicators and targets and up to the operational plan and the current actions of the 
party. As concerns the vision, analyzing the statements concerning the mission of political parties in Romania, regardless of ideology or political orientation, it follows a central element, invoked by most national political parties which gravitate towards democracy and its consolidation. The promotion of the democracy values, pluralism and the rule of law is declarative, the common mission of all political parties in Romania, for which, initiatives and measures deviating from the vision of the democratic course of the country were majorly sanctioned by voters within the electoral consultations. Once defined the vision and mission of the national political system, the parties set their own strategies that imply transposing the values of the political organization into real / operational actions through strategic planning and which are summarized in the sense of Chiocchetti (2016) to two main categories of major strategic goals "public influence and private rewards, since, on the one hand the parties shape public policies, institutions and broadly social relations according to interests and values and, on the other hand, the parties also operate as machines for getting and distributing private benefits to members and their supporters such as personal influence, social status and recognition, psychological awards, employment, money and favors".

In reality, these two goals are interconnected as he acquisition of private benefits by party frameworks depends on gaining the support of civil society actors (voters, members and financiers) and correspond to the interests and concerns of Romanian parties. From the perspectives viewpoint, the customer perspective becomes in the Political Party Balanced Scorecard the perspective of the electorate. As in the case of a company that has the purpose of attracting, maintaining and meeting the customer needs, the electoral performance is the result of a party getting popular support in electoral consultations. On the proposed model, the internal processes in the case of Political Party Balanced Scorecard overlap with the participatory perspective; political parties, in relation to other types of organization, are distinguished through a formal organization embodied in the form of statutes, codes and regulations, of certain governing bodies at local and central level among which there is a close correlation and political programs of whose purpose is materialized in the society governance.

In statutes there are stipulated the guidelines concerning the principles and values on which the party is based and operate, the leadership structure, their duration and method of appointment, the rights and obligations of party members, the position, the attitude of the parties towards the main internal and external issues, general goals, strategy and tactics applied, as well as relations with other political parties and formations. The substantiation and expression of the interests and aspirations of the social class, group whose product is that party are formalized in the form of political programs often promoted in election campaigns. Similarly, learning and growth, from Chiocchetti's (2016) point of view, can be associated in a more generic way with the parliamentary/governmental perspective. If in the case of an economic entity the human resource, through accessing training programs, develops and grows thus consolidating the company's position on the market, in the case of parties, party members who later become members of parliament, have a major role in the legislative process and a considerable influence, which it exerts in the process of government formation.

The projection of human resources from the party level is represented by the mandates of parliamentarians and members of the government, the two entities - the parliament and the government, being two dependent and interconnected bodies due to the 
specific nature of the activity. The direct implications of this aspect are, on the one hand the ability of the party to design effective government programs, as well as the professional capacities, technical skills and personal abilities of the members to implement the proposed government programs, and, on the other hand the degree of involvement of parliamentarians in parliamentary activity and the legislative process, as well as their possibilities to generate effective legislative projects. The financial perspective is similar to both Balanced Scorecard models and refers to the financial performance of the party in attracting public and private funds and the use of financial resources, which in the case of a political party in Romania, comes down to public and private funding.

Getting public financing is conditioned by meeting certain performance criteria provided by the legislation on financing political parties and election campaigns, so that in Romania political parties receive monthly subsidies from the state according to the number of votes acquired in parliamentary elections combined with the number of votes obtained in local public administration elections. The public funds allocation is based on the provisions of the Financing of the activity of political parties and electoral campaigns, Act 2006, according on to the following mechanism:3/4 of amounts are allocated to parties in proportion to the number of votes obtained in parliamentary elections - for parties that exceed the electoral threshold of $3 \%$. Also $1 / 4$ of the total value is divided according to the votes obtained in the local elections for the county councilmen and those from the General Council of the Municipality of Bucharest - for the parties that obtained at least 50 mandates. The low indicate additional funds wich are obtained in proportion to the number of mandates obtained by female candidates. Private financing consists in contributions, donations and loans received by political parties from natural persons or legal entities in the conditions and for amounts provided by the financing legislation of the political parties and election campaigns.

\section{Methodology}

The aim of the research is first of all to define performance indicators with which a political decision-maker can evaluate the activity of his own political party, and which also allows the monitoring of political competitors operating on the national political scene. The second objective of the research is to effectively verify the progress of the indicators proposed at the end of the period under analysis, through a computer application whose architecture is based on the managerial tool for measuring performance Balanced Scorecard adapted to the activity of a political party. The finality of the scientific approach considers the quantification of the party's result in a score obtained for the financial perspective and the parliamentary perspective from the proposed model and respectively for each indicator / sub-indicator related to each perspective. Thus, the application allows the calculation of a final score of the party, depending on which a first quantitative evaluation of the activity of a political entity for the analyzed period can be made.

Starting from this desideratum, the present case study evaluates the activity of a Romanian parliamentary political party, established, traditional (founded in 1992) and ubiquitous on the national political scene, with a vast parliamentary activity present in the Romanian Parliament in the 2016-2020 legislature. The information operated in this research is official public data, related to 2019, disseminated by the competent institutions of the Romanian state responsible for their publication. Even if the analysis in the case of 
financial information seems slightly late, not based on real-time data (the data of the previous year are available to the public, in May of this year), in the case of information on the activity of parliamentarians, some data they could also be available in real time, and can be accessed regularly on the websites of the two Houses of Parliament. Thus, in the future, the premises are created for the development of valid inputs, in real time, regarding the evaluation of the performances of the activity of the political parties at least on some perspectives from Balanced Scorecard.

The need to analyze performance for political parties in Romania based on the design and monitoring of performance indicators has led to a translation of a strategic model for measuring performance within an economic organization to a political organization, in conjunction with the use of a technique performance monitoring Balanced Scorecard used by the business environment and materialized in a computer application BSC Designer Light. The population of the computer program with the specific data of the analyzed political party, as well as the interpretation of the results, considers the analysis of the results of that party following the evolution of the indicators from its own perspective, comparing the results of 2019 with the party's history 2016-2020, practically with 2017, 2018 and 2019, but also with the results registered, on the same indicators, by the political parties active in the Parliament in the same legislatura. Starting from the basic concept of the Balanced Scorecard, after defining the perspectives of the model, for each of them are set in the computer application performance indicators related to activities (initiatives) of interest, and each indicator is assigned a weight in the perspective, so that the sum weights within a perspective should not exceed 1 (100\%), just as the sum of the scores of the prospects should not exceed 1 (100\%).

According to the BSC Designer Light software manual, the final score of the match, calculated as a percentage representing the performance of the analyzed match, resulted from the application of the weighted average formula for each perspective as well as for the whole and depends by setting some parameters in the computer program.

In the minimum version of the application (Light version), you can analyze, evaluate and calculate the progress of the established indicators, depending on 3 parameters: "value," "baseline" and "target", with the possibility to extend the analysis by another 2 parameters "maximum"and "minimum". In this case study for the simplification of the model we started from the premise that "target" = "maximum" is the target is maximum for the analyzed indicator and respectively "baseline" = "minimum" is the starting line is at a minimum level accepted for the indicator analyzed. Each indicator / sub-indicator is assigned in the "target" field a value for the target of that indicator, equivalent to the maximum target value for that indicator, a value for the "baseline" field, which represents a minimum, basic value, from which to start. monitoring for that indicator, as well as the resulting value of the analyzed indicator, which, in this case, is equal to the result obtained by the analyzed political party at the end of 2019 (31.12.2019). The progress of that indicator shall be calculated in the form of a score, obtained by applying the formula:

$$
\text { Progress }=(\text { Value }- \text { Baseline }) /(\text { Target }- \text { Baseline }) \text {. }
$$

At the same time, the application sets, for each indicator, the weight allocated to it in perspective, as well as the optimization of the indicator which refers to maximizing or minimizing the values of the targeted indicator. For example: within the financial 
perspective, optimization can take into account the maximization of contributions, because the contributions of a political party in Romania are not capped by law and a higher value of contributions would lead to a better final score of the party, and in the parliamentary perspective, it is considered to minimize the absences of the party's parliamentarians to the voting action in the parliamentary sittings. The application also allows the setting of different units of measurement for each indicator / sub-indicator (score, RON, Yes / No, etc.) and can highlight the individual progress of the indicator and graphically, with red marker for a progress of $20 \%$, orange marker for $40 \%$, light green for $60 \%$ and green for a progress of at least $80 \%$.

\section{Balanced scorecard designer light customization for political parties}

\section{Defining perspectives in BSC Designer Light}

The main objective of this paper is to evaluate with the help of the computer application BSC Designer Light the performance of a political party in Romania, operating with 2 perspectives from the 4 perspectives provided by the theoretical model of Balanced Scorecard, the financial one we find in the model theoretically proposed by Kaplan and Norton $(1992,1996)$ and a parliamentary perspective that is specific to the activity of political parties. Both areas of analysis were given an equal share of 0.5 (50\%) in the proposed model, both for the financial and the parliamentary perspective. The motivation for this allocation lies in the fact that parliamentary activity reflects both the importance of Parliament as the supreme legislative forum and the "dependence" of the Government on the political parties in the parliamentary majority that guide government policies, including the appointment of the Executive. Equally, the financial perspective highlights the importance of financing a political party regardless of the source of funding, private or public, a component without which the party cannot operate on the political stage. There is also an interdependent relationship between the two perspectives, according to which the public funding of a Romanian political party depends $75 \%$ on the results obtained in the parliamentary elections, as private funding and the contribution of financial resources during election campaigns can determine the success of a political party in elections.

\section{Defining indicators and sub-indicators in the financial perspective}

Within the financial perspective, for the analyzed party, 2 performance indicators were set: private financing and public financing. Private financing contains 4 subindicators related to the sources of private financing provided by Law 334/2006 contributions, donations, loans and revenues from other sources such as subletting the party's own spaces for organizing parliamentary offices. The second indicator, public funding, is materialized in the form of a monthly subsidy that parliamentary parties receive from the state, through the budget of the Permanent Electoral Authority, as long as it complies with the legal provisions regarding the destination of these amounts. The share allocated to each indicator in the financial perspective was established on the proposed model, in the amount of 0.9 (90\%) for private financing with the 4 related sub-indicators and $0.1(10 \%)$ for public financing, so that the sum of the indicators from the financial perspective should be equal to $1(100 \%)$. The rationale for this distribution is that private funding requires effort and financial discipline on the part of a political party, resource consumption in determining the amount of contributions and their monthly collection, 
identifying donors and collecting all amounts from other sources, with mainly from the subletting of spaces for the organization of parliamentary offices, which led to a share of $0.9(90 \%)$ in the financial perspective.

On the other hand, even if the form of public funding is predominant in the total revenue of a political party, about $80 \%$ of total revenue comes from the state, the share of $0.1(10 \%)$ allocated in the Balanced Scorecard for public funding, is associated with efforts and a minimum consumption of resources by a political party, as this form of funding is granted according to the results obtained every 4 years in electoral consultations (75\% results of parliamentary elections and 25\% results of local public administration elections), consultations which in turn benefit from funding related to election campaigns distinct from the current activity of the party. The total budget of public and private financing for 2019 for the parliamentary parties in Romania was 318.559.792 RON, according to the official data existing on the website roaep.ro and banipartide.ro, published in the Official Gazette of Romania. Of this amount, the subsidy granted by the state to these parties amounted to 252.621 .220 RON, which represents $79.3 \%$ of the total financial income related to political parties, an important and unconditional share of any performance or any result from the beneficiaries, to determine access to these funds. In addition, the amounts from public financial resources are relatively constant for 4 years, and changes can only occur as a result of changes in legislation made at the initiative of beneficiaries / parliamentary parties and are valid for all parliamentary parties. At the same time, the granting of the subsidy is conditioned by a single legislative criterion regarding the observance of the destinations provided by law for the expenses from these funds, expenses that cover in an overwhelming majority the functioning needs of a political organization.

From the reports published on the website of the Permanent Electoral Authority, an institution empowered to control the financing of the activity of political parties and electoral campaigns in Romania, it results that all eligible parties in the 2016-2020 legislature, including the analyzed party, received monthly state subsidy with the exception of the National Union for the Progress of Romania, a party that was not represented in parliament in the mentioned legislature. Within the financial perspective to allocate shares to each sub-indicator, we started from the examination of the amount of 113.234.805 RON, which represents the total value of private financing in the analyzed legislature, but for 3 years $(2017,2018,2019)$, for which there are published data, from the same sources mentioned above. The value of private financing during this period is composed of contributions in the amount of 66.430.278 RON, donations in the amount of 10.443 .420 RON, loans of 28.731.728 RON and income from other sources in the amount of 7.599.378 RON, which leads to a share for each source of financing in total private financing in the amount of 0.6 (60\%) for contributions, 0.1 (10\%) for donations, $0.25(25 \%)$ for loans and 0.05 respectively (5\%) for income from other sources. Given that loans, by their legal nature, need to be repaid and the model set out does not aim to analyze the performance of expenditure because there is no public information on payments and expenditure of political parties, this sub-indicator has been assigned a share of $0.1 \% 10 \%$ ) of the total private financing, the remaining 0.9 (90\%) being distributed according to the contributions of each source of income to the private financing.

Thus, the following weights were operated in the IT application: for the contribution sub-indicator 0.65 (65\%), for the donations sub-indicator 0.2 (20\%) and for the sub-indicator income from other sources 0.05 (5\%). 
Progress of indicators and sub-indicators from a financial perspective

To assess the progress of these indices, the score was calculated taking into account the function of maximizing the sub-indicators and applying the aforementioned formula, which depends on the value obtained by the party analyzed in 2019, relative to the target and baseline. The budget for contributions was set starting from the comparison of the total value of the contributions of all parliamentary parties in 2018 which was in the amount of 21.150.119 RON, with the total value of the contributions of the same parties in 2019, which was 26.845.119 RON, resulting in a general increase of $27 \%$ of contributions. For the analyzed party to make progress, it should record revenue from dues in 2019, at least $27 \%$ higher than dues collected in 2018. Similarly, for the donations sub-indicator, the target value was set according to the total evolution of donations in 2019 compared to 2018, resulting in a 7 times higher increase in this segment (8.191.079 RON in 2019 versus 1.168.369 RON in 2018), while for the sub-indicator revenues from other sources, there was a decrease of 6\% from 2.395.328 RON to 2.253.401 RON.

The baseline parameter was set similarly for each sub-indicator and was set to the historical minimum value in the legislature for the analyzed party. Following the application of the formula, Progress $=($ Value - Baseline $) /$ (Target - Baseline) resulted in a score, above average for the contribution sub-indicator, of $68.08 \%$ due to a considerable level of party contributions at the end of 2019 amounting to 10.062.248 RON and a negative score of $-5.56 \%$ for donations, due to the fact that the analyzed party, in 2019 , received donations of only $46.000 \mathrm{RON}$ amount below the baseline level of 69.000 RON and below the set target of $483.000 \mathrm{RON}$. Regarding the sub-indicator revenues from other sources, it also registered a significant progress of $69.95 \%$ a performance due to the fact that the party has the largest number of parliamentarians and the revenues in this category come mainly from the subletting of party housing for the organization of parliamentary cabinets, including at the territorial level. In the case of the loan sub-indicator, starting from the need to return them and from the conclusion that in 2017 and 2018 only 2 parties out of 7 resorted to this source of financing with insignificant loan values for one of them (2.900 RON in 2017 and 1.930 RON respectively in 2018), the unit of measurement of progress for this sub-indicator was set "Yes / No", in the sense that a party that has no loans was considered to be performing, fact for which for 2019, the result was passed "Yes" because the analyzed party contracted loans, "No" was applied to the target because the objective was not to contract loans and baseline "No" because historically the party did not register loans. This context has led to a score of $0 \%$ which does not require a certain interpretation, but indicates that the party used to finance loans that must be repaid according to the legislation in force within 2 years.

The same unit of measurement with "Yes / No" was used in the case of the public funding indicator, motivated by the fact that all parties in the legislature receive the subsidy from the state, without a real consumption of resources, which motivated the allocation of $0,1(10 \%)$ in total perspective. In this case, in the computer application, the result was "Yes" because the analyzed party received public funding, the target was also operated "Yes" because the goal was to obtain the grant and the baseline also "Yes" "Because the party has access to that funding every year. In this case, too, the monitored indicator did not progress, the score for the Balanced Scorecard Public Financing index being $0 \%$.

For a better visualization of the parameters and the associated values, a synthesis of this information was made which is presented in Table no.1. 
Table 1. Indicators and parameters financial perspective

\begin{tabular}{|c|c|c|c|c|c|c|}
\hline KPI & Progress & Value & Baseline & Target & Measure & Weight \\
\hline Private financing & $46,64 \%$ & $\begin{array}{c}\text { Not } \\
\text { applicable }\end{array}$ & $\begin{array}{c}\text { Not } \\
\text { applicable }\end{array}$ & $\begin{array}{c}\text { Not } \\
\text { applicable }\end{array}$ & $\%$ & 0,90 \\
\hline Contributions & $68,08 \%$ & 10.062 .248 & 8.499 .854 & 10.794 .814 & RON & 0,65 \\
\hline Donations & $-5,56 \%$ & 46.000 & 69.000 & 483.000 & RON & 0,20 \\
\hline $\begin{array}{c}\text { Revenue from } \\
\text { other sources }\end{array}$ & $69,95 \%$ & 729.984 & 899.917 & 656.986 & RON & 0,05 \\
\hline Loans & $0,00 \%$ & Yes & Yes & No & Yes/No & 0,10 \\
\hline Public financing & $0,00 \%$ & Yes & Yes & Yes & Yes/No & 0,10 \\
\hline
\end{tabular}

The score of the financial perspective for the analyzed party, calculated based on the weights and parameters set in the computer program, was $41.97 \%$ signaled by the application with yellow marker according to the screenshot below.

Figure 2. Screenshot BSC Designer Light application - Financial Perspective

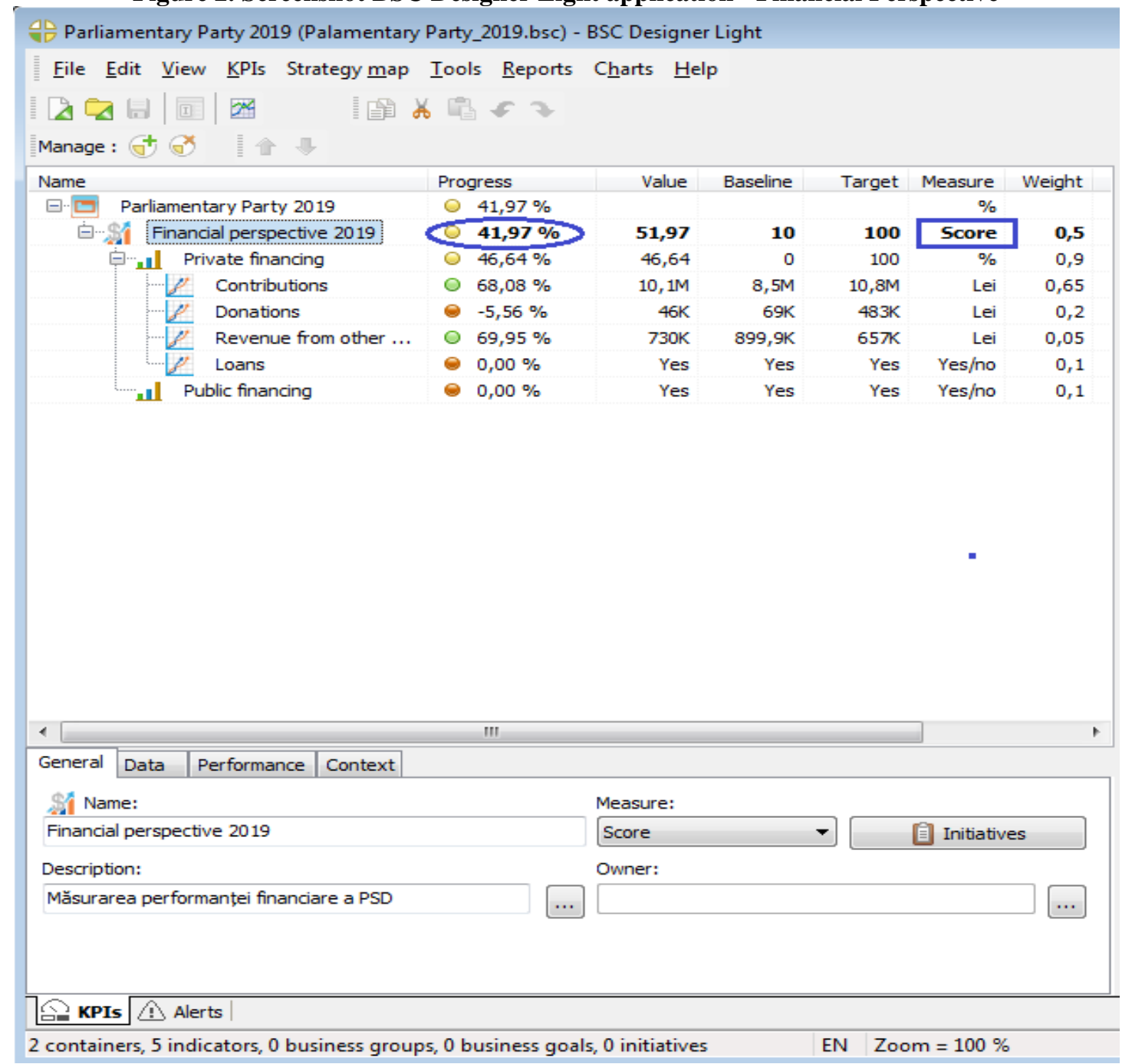


Defining indicators and sub-indicators in the parliamentary perspective

Within the parliamentary perspective, starting from the provisions of the Romanian Constitution, according to art. 61, par. (2), the Romanian Parliament is bicameral, consisting of the Chamber of Deputies and the Senate. Thus, this organizational structure was replicated in the proposed Balanced Scorecard model, which is why 2 indicators were allocated to the parliamentary perspective, representing the 2 chambers of Parliament, respectively the Indicator - Chamber of Deputies and the Indicator - Senate. The distribution of the weights of the 2 indicators was based on the revision of the Constitution, which eliminated the mediation procedure between the two Chambers of Parliament in the case of organic and ordinary laws and introduced the division of powers between the Chamber of Deputies and the Senate Parliament, from symmetrical, to asymmetrical chambers. According to Popa's (2018) analysis, from the point of view of legislative proposals, this asymmetry had as an affect, a distribution of legislative projects on each Chamber depending on the regulatory field, resulting that, "out of 83 regulatory areas by law to which the Constitution mentions, in 61 of them the final decision belongs to the Chamber of Deputies and only in 21 of them the final decision belongs to the Senate.

Therefore, in terms of a quantitative method of evaluation, we can say that "it is not the Senate that is the most important chamber, as it is often said among the public, but the Chamber of Deputies". Corroborating this quantitative analysis with the number of parliamentarians belonging to each Chamber in the 2016-2020 legislature, respectively 329 deputies and 136 senators, within the parliamentary perspective was assigned, in the Balanced Scorecard model for the analyzed political party, a weight of 0.7 (70\%) for the Indicator - Chamber of Deputies and a weight of 0.3 (30\%) for the Indicator - Senate, thus respecting the basic principle according to which the sum of the weights of the indicators from a perspective to be equal to 1 or $100 \%$. The definition of the sub-indicators of each indicator from the parliamentary perspective had as a starting point the consistency of the activity of the parliamentarians of the analyzed party and of the parliament as a whole. Although in the parliamentary elections of December 2016, according to theinformation on the website of the Central Electoral Bureau, the political party in question obtained 67 senator seats and 154 seats, the average for 2019 places them at 69 senators and 145 deputies in consistent with the data available on the websites of the two chambers of Parliament. Compared to the same sources, in terms of attendance at voting in 2019, the Senate registered 1,171 voting subjects (of which 718 voting were common with the Chamber of Deputies) and an average turnout on the party monitored by only 60\%, which led to a $40 \%$ absenteeism from party members in the Senate. In the Chamber of Deputies in 2019, 1,425 voting subjects were registered, which include both bills, draft decisions of the Chamber, amendments, etc., with an average turnout of $71 \%$. From the point of view of public opinion, the theoretical target of $100 \%$ presence in Parliament is obvious, but from the perspective of a political party, absenteeism in this case $29 \%$ in the Chamber of Deputies and $40 \%$ in the Senate, respectively, must be analyzed in the context of interest party on the laws and voting actions in which it chooses to participate.

In this case, the establishment of sub-indicators was based on the main actions taken by parliamentarians so that, for the Chamber of Deputies were monitored: the number of legislative proposals initiated by party deputies, amendments to legislative projects, the number of questions and interpellations addressed, and the number political statements, related to the number of Members who made questions, interpellations and political 
statements respectively and who recorded an average annual speaking time in the debates of 4,809 minutes.

In summary, there were 5 sub-indicators for the Chamber of Deputies which were assigned an equal share in the indicator, of 0.2 (20\%) for each sub-indicator, respecting the principle according to which the sum of the sub-indicators should be equal to $1(100 \%)$. For the Senate, in terms of specific activities and existing data, 5 sub-indicators similar to those related to the Chamber of Deputies were monitored, namely the number of legislative proposals initiated by party deputies, the number of questions and interpellations addressed, the number of political statements compared to the number of senators questions, interpellations and political statements. The indicator on the tabled amendments was not analyzed because there is no information on this issue, instead, the activity reports (11) prepared by civil servants on the activity carried out by the Senate in 2019, report data on censure motions, which allowed the introduction in the analysis of this sub-indicator.

In conclusion, for the Senate also resulted similarly 5 sub-indicators which accounted for a share of 0.2 (20\%) for each, in compliance with the basic rule that, the total sub-indicators within an indicator is equal to 1 (100\%).

\section{Progress of indicators and sub-indicators from a parliamentary perspective}

As in the case of the financial perspective, and for the parliamentary perspective, in order to assess the progress of the evaluated indices, the score was calculated taking into account the function of maximizing sub-indicators and applying the known formula, which depends on the value obtained by the party analyzed in 2019 target and baseline. The setting of the target and baseline parameters for the indicators from the parliamentary perspective in the Balanced Scorecard was done from a different perspective from the indicators from the financial perspective where, in order to assess financial progress, a usual method was used to compare the financial result of the analyzed year with the result previous. In the case of the parliamentary perspective, the parliamentary activity of 2019 compared to 2018 registered a decrease in intensity on all monitored issues and for all parties in the legislature and the use of the same target setting model, coupled with the large number of MPs the party has, would have led to the conclusion that the political party could have performed in comparison with the competing parties, which is why, in establishing the parameters of this perspective, we started from the specificity of the parliamentary activity.

Any political party aims to win electoral consultations, and in the case of a national, traditional, established political party, like the one analyzed, obtaining a parliamentary majority is a strategic objective, of utmost importance, which depends directly on the results obtained in electoral consultations. Although the political party in the model presented, in the 2016 parliamentary elections recorded a very good score, of $49.26 \%$ in the Senate, where it won 67 seats out of a total of 136 seats provided by law and $46.80 \%$ in the Chamber of Deputies where he was assigned 154 seats out of a total of 329 seats, however he did not obtain the parliamentary majority. From this point of view, starting from the premise that the main role of the Parliament is to legislate and the translation of this purpose at the level of parliamentary activity is materialized in the legislative proposals initiated by parliamentarians, the target of the sub-indicators legislative proposals from the parliamentary perspective. The Chamber of Deputies, as well as for the Senate indicator, was set on obtaining the majority according to the principle of electoral consultations where 
the absolute (or simple) majority represents the number of votes equal to at least half plus one of the total votes.

The progress of the other sub-indicators for 2019 was evaluated according to the number of actions of the parliamentarians of the analyzed party compared to the number of parliamentarians who initiated the actions, compared to most parliamentary actions in 2019 for all political parties in the legislature, and the baseline was established in the same way from a financial perspective and was set at the historical minimum value in the legislature for the analyzed party. For the Chamber of Deputies, in the case of the subindicator of legislative proposals, it started from a total of 673 legislative projects submitted to the Chamber of Deputies in 2019, of which 233 had as initiators and representatives of the analyzed party. The target was set at 337 initiatives and the baseline was 175 representing the lowest number of legislative proposals of the party in 2017-2019.

Regarding the sub-indicators questions, interpellations and political statements, the existing data refer both to the number of deputies who initiated these actions and to the total number of actions both on each parliamentary party and on each year of the analyzed period. Thus, based on the action / parliamentary report, it was possible to evaluate the progress of the sub-indicators of the analyzed party by setting the target for 2019 as the average of the action / parliamentary report for each specific activity undertaken by deputies of all component parties in the Chamber of Deputies. the equivalent of the smallest action / parliamentary ratio in the history of the analyzed party. Both parameters used in the calculation formula, together with the result of the action / parliamentary report registered by the party in 2019, and determined the final score of each sub-indicator.

Specifically, for the calculation of the score of the question sub-indicator, from the Chamber of Deputies, the existing public information for 2019 reveals a total number of 2,803 questions asked by 250 deputies of all parties, which leads to a result of 11.21 questions / deputy, level at which was the target of this sub-indicator. The baseline was set at 6.87 as the result of the question / deputy ratio in 2017 when 694 questions were asked by 101 deputies of the analyzed party, and the result of the party in 2019 was 10.79 obtained from reporting 691 questions to 64 parliamentarians who took this action.

Regarding the sub-indicator of interpellations in the Chamber of Deputies, on the same principle, the target was set at the value of 3.62 obtained by reporting all 457 interpellations to 126 initiating deputies, the baseline at the value of 2.98 registered by the party in 2017 when 81 deputies launched 242 interpellations, and the year 2019 brought a result below the one registered in 2017, of 2.44, because only 88 interpellations were issued by 33 deputies. In the case of the sub-indicator of political statements related to the Chamber of Deputies, the party registered in 2019 a statement / deputy ratio of 7.76 (846 political statements / 109 deputies) higher than the target set at 6.66 from a total of 1834 political statements in the Chamber Deputies supported by 275 deputies of all political parties and higher than the baseline of 5.19 also in 2017 (670 statements / 129 deputies).

By applying the known formula, scores were obtained for these sub-indicators above the target as in the case of political statements of $174.38 \%$, a very good result of $88.25 \%$ for questions, below expectations for legislative proposals or even negative for interpellations $(-84,37 \%)$. Within the Chamber of Deputies indicator there is also a 5th sub-indicator amendments, which evaluates the activity of deputies according to the amendments tabled in 2019. For this reasoning on setting the target and baseline parameters was similar to the statement that the baseline was set at the level of the result of this activity in 2019 as the 
lowest result recorded by the party on the criterion of amendments was in 2019, when the party tabled only 292 amendments versus 608 in 2018 and 784 in 2017. With a target in 2019 of 345 amendments to the level of the majority and a result of 292 amendments, a score of $0 \%$ was obtained, no progress, because the result of the party for 2019 was at the level of the baseline.

The setting of the parameters of the sub-indicators from the parliamentary perspective on the indicator of the Chamber of Deputies is summarized in the table below:

Table 2. Indicators and parameters Chamber of Deputies from the Parliamentary Perspective

\begin{tabular}{|c|c|c|c|c|c|c|}
\hline KPI & Progress & Value & Baseline & Target & Measure & Weight \\
\hline $\begin{array}{c}\text { The Chamber of } \\
\text { Deputies }\end{array}$ & $42,90 \%$ & $\begin{array}{c}\text { Not } \\
\text { applicable }\end{array}$ & $\begin{array}{c}\text { Not } \\
\text { applicable }\end{array}$ & $\begin{array}{c}\text { Not } \\
\text { applicable }\end{array}$ & \% & 0,7 \\
\hline $\begin{array}{c}\text { Legislative } \\
\text { proposals }\end{array}$ & $35,80 \%$ & 233 & 175 & 337 & Score & 0,2 \\
\hline Questions/ Deputies & $88,25 \%$ & 10,7 & 6,8 & 11,21 & Score & 0,2 \\
\hline $\begin{array}{c}\text { Interpellations/ } \\
\text { Deputies }\end{array}$ & $-84,37 \%$ & 2,44 & 2,98 & 3,62 & Score & 0,2 \\
\hline $\begin{array}{c}\text { Political statements/ } \\
\text { Deputies }\end{array}$ & $174,83 \%$ & 7,76 & 5,19 & 6,66 & Score & 0,2 \\
\hline Amendments & $0 \%$ & 292 & 292 & 345 & Score & 0,2 \\
\hline
\end{tabular}

Taking into account the quotas allocated to each sub-indicator, the score of the Chamber of Deputies indicator from the parliamentary perspective of the Balanced Scorecard for the analyzed party, calculated based on the weights and parameters set in the computer program, was $42.90 \%$, signaled by the application with yellow marker, according to the screenshot below.

Figure 3. BSC Designer Light application - Chamber of Deputies Indicator



In the case of the Senate indicator, room in which in 2019 the analyzed party obtained the majority by transferring 2 senators from other political parties represented in the Senate, thus registering a monthly average of 69 senators compared to 67 seats obtained 
in elections, for the sub-indicator proposals legislative from this perspective a score of $270.59 \%$ was registered. The progress was due to a number of 165 legislative projects in which the party senators were among the initiators out of a total of 272 legislative proposals registered in the Senate in 2019. The target was set at 136 legislative projects and the baseline was 119 representing the smallest number of legislative projects of the party in the period 2017-2019. Regarding the sub-indicators questions, interpellations and political statements, and in the case of parliamentary activity in the Senate there is information on both the number of senators initiating these steps and the total number of actions both on each parliamentary party and each year in the period. Therefore, as in the case of the Chamber of Deputies indicator, based on the action / parliamentary report, the progress of the sub-indicators of the analyzed party was monitored and the target for 2019 was defined as the average of the action / parliamentary report for each specific activity carried out by parliamentarians. Senate, and the baseline as the equivalent of the smallest action / parliamentary ratio in the history of the analyzed party. Both parameters used in the calculation formula, together with the result of the action / parliamentary report registered by the party in 2019 in the Senate, and determined the final score of each sub-indicator.

Thus, for the calculation of the score of the question sub-indicator, related to the Senate indicator, the data published by the Parliament signal in 2019, a total of 760 questions asked by 246 senators of all component parties, which leads to a result of 3.08 questions / senator, the level at which the target of this sub-indicator was set. The baseline was set at 2.06 as the result of the question / senator ratio from 2017 when 277 questions were asked by 134 senators of the analyzed party, and the result of the party in 2019 was 1.70 obtained from reporting 235 questions to 138 senators who made this move to ask questions.

For the interpellation sub-indicator, keeping the same principle, the target was set at 2.17 obtained by reporting all 535 interpellations to 246 initiating senators, the baseline at 1.37 registered by the party in 2017 when 134 senators addressed 184 interpellations, and the year 2019 brought a result below the one registered in 2017, of 1.19, because 165 interpellations were issued by 138 senators of the party. In the case of the sub-indicator of political statements related to the Senate indicator from the parliamentary perspective of the Balanced Scorecard, the party registered in 2019 a statement / senator ratio of 2.35 (325 political statements / 138 senators) approximately equal to the target set at 2.32 out of a total of 571 political statements in the Senate supported by 246 senators of all political parties and less than the baseline of 3.19 also in 2017 (428 statements / 134 senators).

Applying the calculation formula used by the computer program, scores above expectations were obtained for these sub-indicators as in the case of legislative proposals (270.59\%), negative results of $-35.29 \%$ and $-22.50 \%$ for questions and interpellations, respectively, and far below expectations for political statements (3.45\%). For the diversity and complexity of the model and because the motion of censure is a parliamentary activity of utmost importance that creates the opportunity to change the Government or one or more ministers of the Executive in the formation of a majority, the sub-indicator of motion of censure was defined in the Senate indicator. of the existence of this information in the activity reports of the Senate. In this category, at the end of 2019, when the evaluated political party was in opposition to the Senate, the analyzed party submitted a simple motion against the Government, initiated by 41 senators of the party and which was adopted with a number of 59 votes "Yes", 56 votes "No" and 2 abstentions. 
Given the particularity of this sub-indicator, its analysis was done from a qualitative point of view, the unit of measurement for establishing the score being selected with the option "Yes / No". Thus, the target was passed "Yes" in the sense that the objective was to adopt the motion, the baseline was passed "No" because the party did not have a parliamentary majority and there was a possibility that the motion would be rejected and the value was checked in the application "Yes", because the result was the adoption of the simple motion submitted. On this reasoning, the score for this sub-indicator was $100 \%$.

The setting of the sub-indicators parameters from the parliamentary perspective on the Senate indicator is summarized in the table below:

Table 3. Indicators and parameters Senate from the Parliamentary Perspective

\begin{tabular}{|c|c|c|c|c|c|c|}
\hline KPI & Progress & Value & Baseline & Target & Measure & Weight \\
\hline Senate & $63,25 \%$ & $\begin{array}{c}\text { Not } \\
\text { applicable }\end{array}$ & $\begin{array}{c}\text { Not } \\
\text { applicable }\end{array}$ & $\begin{array}{c}\text { Not } \\
\text { applicable }\end{array}$ & $\%$ & 0,3 \\
\hline Legislative proposals & $270,59 \%$ & 165 & 119 & 136 & Score & 0,2 \\
\hline Questions/ Deputies & $-35,29 \%$ & 1,7 & 2,06 & 3,08 & Score & 0,2 \\
\hline $\begin{array}{c}\text { Interpellations/ Deputies } \\
\text { Political statements/ } \\
\text { Deputies }\end{array}$ & $-22,50 \%$ & 1,19 & 1,37 & 2,17 & Score & 0,2 \\
\hline \begin{tabular}{c} 
Motions of censure \\
\hline
\end{tabular} & $100 \%$ & Yes & No & Yes & Yes/No & 0,2 \\
\hline
\end{tabular}

The score of the Senate indicator from the parliamentary perspective of the Balanced Scorecard for the analyzed party, calculated based on the weights and parameters set in the computer program, was $63.25 \%$ signaled by the application with green marker according to the screenshot below.

Figure 4. BSC Designer Light application - Senate Indicator

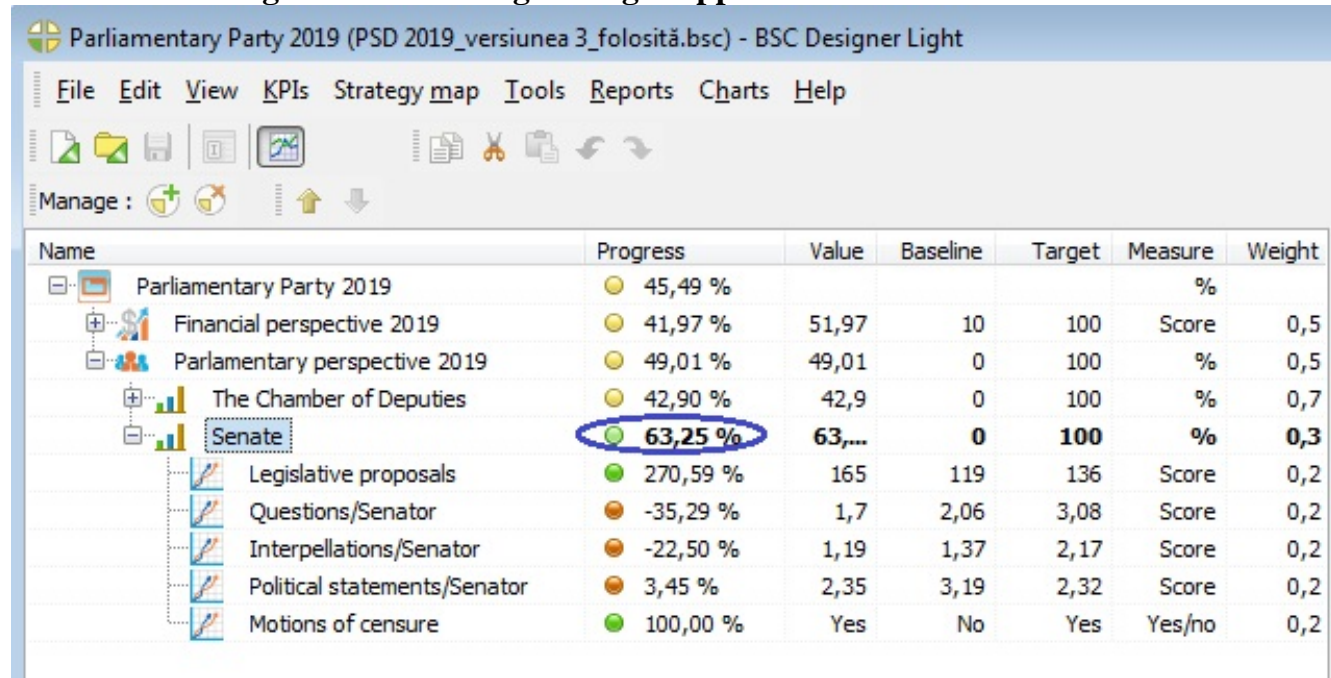

The score of the parliamentary perspective for the analyzed party, calculated based on the weights and parameters set in the computer program, was $49.01 \%$ signaled by the application with yellow marker according to the screenshot below. 
Figure 5. BSC Designer Light application - Parliamentary Perspective

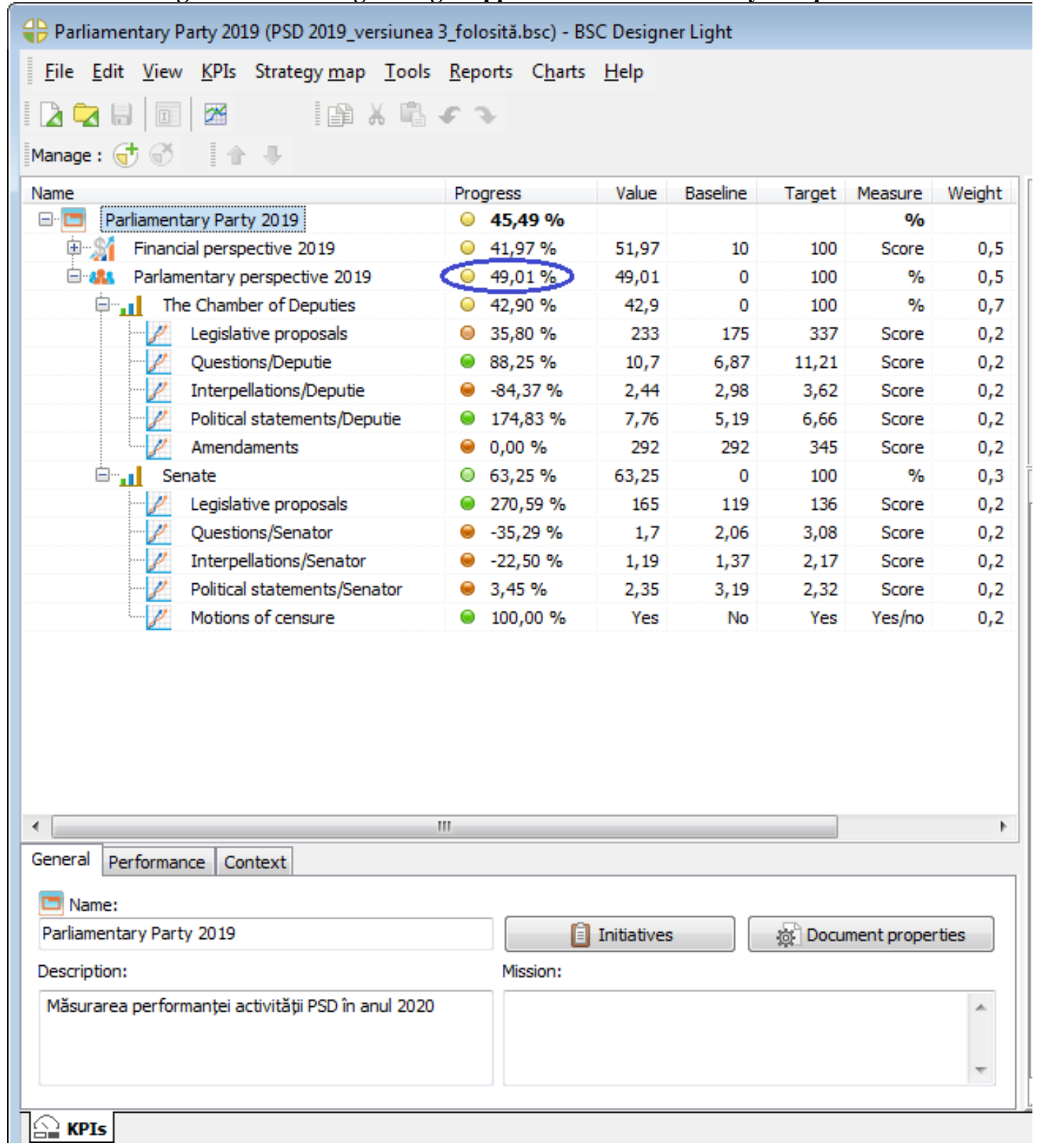

Summarizing the whole model, based on the score obtained by each sub-indicator, which determines the score of each indicator and implicitly the score of each perspective, depending on the weights assigned to each index in the Balanced Scorecard (sub-indicator, indicator and perspective) resulted in the final score of the political party. amount of 45.49\% which signals the progress of the activity of the political party in 2019 versus previous years and in comparison with the evolution of other parliamentary policies.

The overview of the Balanced Scorecard for this match is given below, in detail, at the level of each sub-indicator. 
Figure 6. BSC Designer Light application - extended version

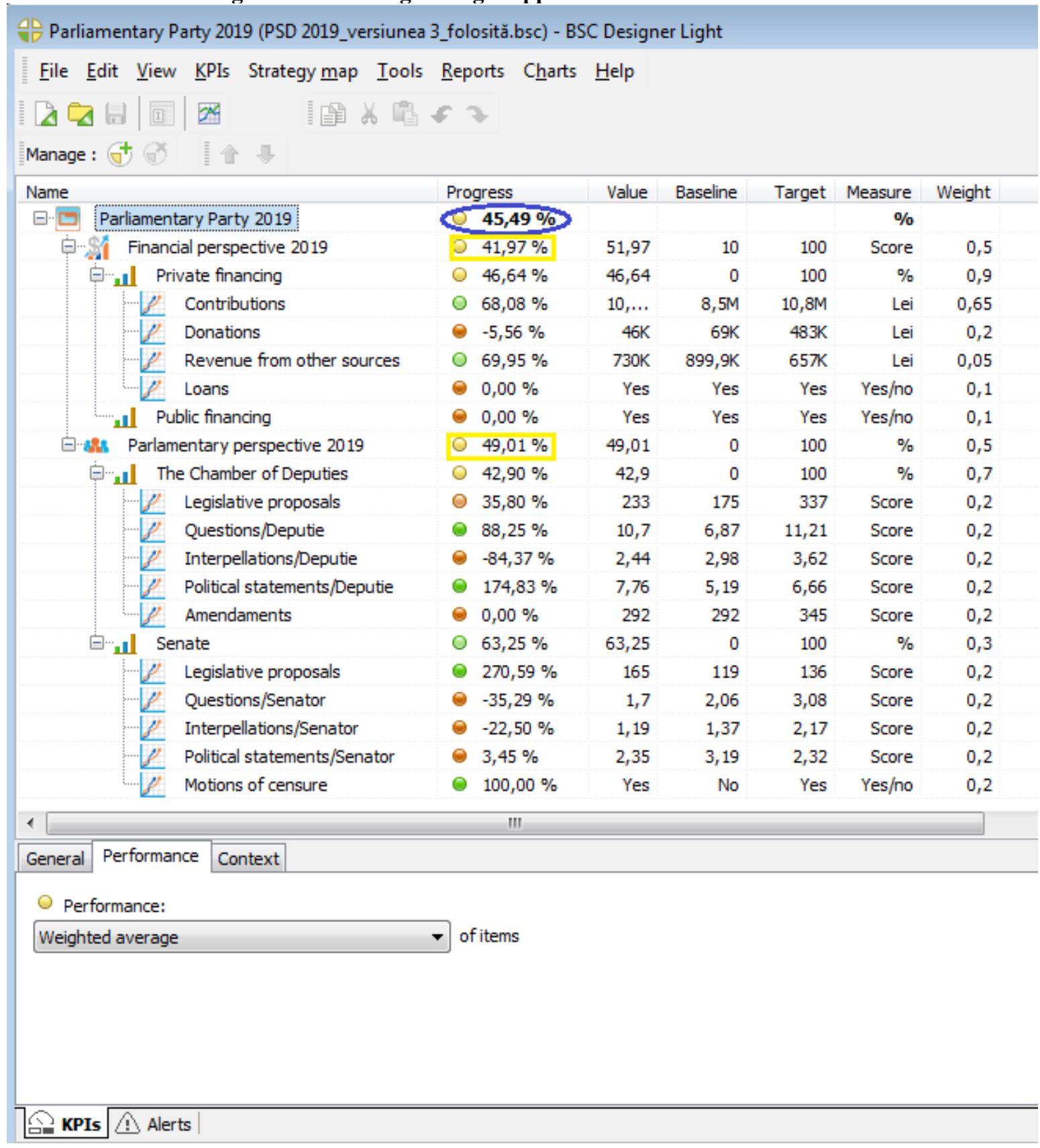

The progress of the political party can be viewed graphically with the help of the computer application BSC Designer Light, according to the image below: 
Figure 7. BSC Designer Light application - graphical representation

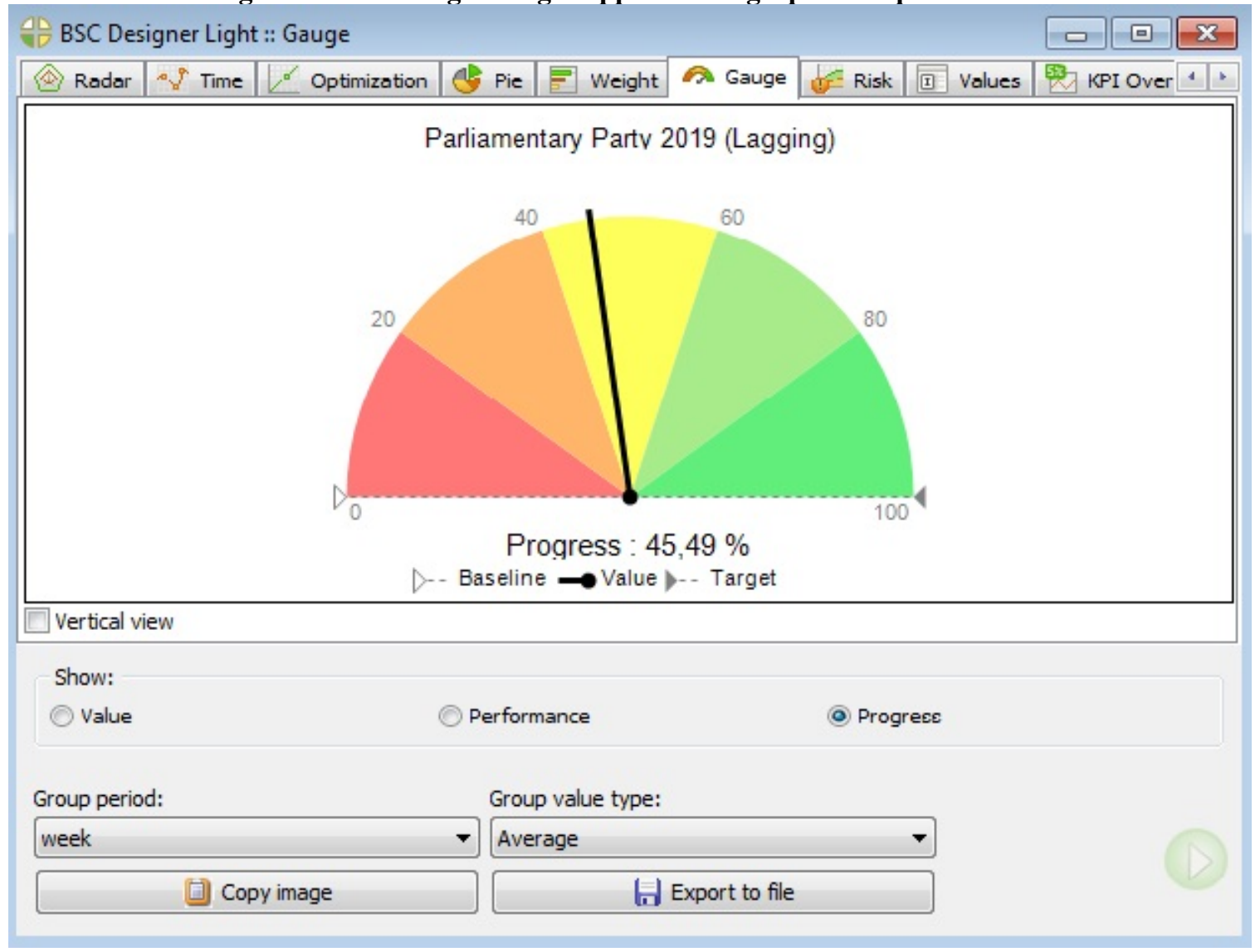

\section{Conclusions and discussion}

The score of $45.59 \%$ obtained by the analised party in 2019, can be interpreted as a performance from the perspective of financial indicators fees and revenues from other sources, areas where the party obtained significant percentages $68.08 \%$ and $69.95 \%$ or even $88 \%$, respectively, $25 \%$ in the case of the sub-indicator questions from the parliamentary perspective related to the Chamber of Deputies. Also, results obtained above expectations on the sub-indicator of political declarations in the Chamber of Deputies of $174.83 \%$ and a real performance was registered in the Senate where on the sub-indicator of legislative proposals it obtained a score of $270.59 \%$. On the other hand, in the financial perspective there was a focus area for the party, that of donations where the result was negative $-5.56 \%$. Equally, efforts must be focused on parliamentary activity, especially in the Senate, where although the party has the most seats and has a majority in 2019, it still recorded results below expectations, even negative on certain indicators. Without being able to scientifically argue a possible link between the results obtained in the 2016 parliamentary elections and the result of this analysis, it can still be seen that the overall level of party performance of $45.49 \%$ is relatively similar to the performance obtained in the parliamentary elections (49, 26\% in the Senate and 46.80\% in the Chamber of Deputies), 
speculating that the party maintained a standard and a guideline of over $40 \%$, which it followed 3 years after the elections.

At the same time, the result of $45.59 \%$ still supports a series of interpretations, in the sense that the score is obtained by analyzing the activity on the reasoning presented and only on 2 financial and parliamentary perspectives, from the 4 perspectives that the theoretical model of Balanced Scorecard provides. From this point of view, the research can be extended by a political party and evaluated the activity and from another perspective such as that of the internal activity. In this area, the national parties with well-defined internal organizational structures and extended territorial representation, have internal information related to the number of party members, the number of active members and their monthly evolution, migration of members from one party to another, and activity data territorial of the party and of the elected representatives in the local administration: mayors, local councilors, presidents of county councils and county councilors.

Also within the internal perspective, performance indicators could be defined for political marketing actions, in which performance indices could be established for the activity in traditional media (TV, radio, print, outdoor), online appearances. and social media, an area in which performance indices are very clearly defined. In order to be able to evaluate the entire activity of a political party, another perspective to be analyzed according to the proposed theoretical model could be the electoral perspective to analyze the party's electoral performance, election scores, mandates of parliamentarians and local public administration representatives.

In the final assessment of the performance of a political party, the quantitative analysis could be doubled by a qualitative analysis of the perspectives and indicators set in the BSC. Evaluations regarding the negotiations on obtaining majorities in local councils and county councils are aspects related to the political game and have a decisive role in the development of party projects at the level of local administrations. Also, the quality of the party's human resources, the training and experience of party members promoted to ministers, state secretaries, undersecretaries of state, is crucial in terms of the capacity to implement the national political program of government.

The opportunity and efficiency of the current expenses of the party, the internal structure of the party as well as the way of electing the representatives of the superior forums, leading the party together with the control of the state public institutions by promoting in their leading positions the members of their own party quantifiable, but which play a major role in how the party evolves and performs on the national political scene.

This paper, in addition to limitations on the accessibility of information on the activity of political parties, also has a barrier imposed by the Balanced Scorecard method that can generally be applied to entities with a complex activity, where there is a recurrence of data and well-defined strategic objectives. From this perspective, the presented concept can be implemented by the big political parties, where there is a recurrent, constant flow of information and human resource with attributions in the continuous monitoring and evaluation of the activity. 


\section{References}

1. Appleton, A. and Ward, D. (1997). Party Response to Environmental Change: A model of Organizational Innovation.Party Politics. Vol. 3, p.341.

2. $\quad$ Anthony, S.; Viguerie, P.; Waldeck, A. (2016). Corporate Longevity: Turbulence Ahead for Large Organizations; Half of S\&P 500 Companies are Expected to be Replaced Over the Next 10 Years, and a New Survey Points to Organizational Inertia and Lack of Long-term Vision. Boston: Harvard Business Review Press, Boston.

3. Central Electoral Bureau of Romania, (2016). Minutes on the final results of the Senate elections.

4. Central Electoral Bureau of Romania, (2016). Minutes on the final results of the elections for the Chamber of Deputies.

5. Chiocchetti, P. (2016). Measuring Party Strength: A New Systematic Framework Applied to the Case of German Parties, 1991-2013. German Politics. 25(1), p.84.

6. Damgaard, B. and Lewis, J.M. (2014). Citizen participation in public accountability.Oxford Handbook of Public Accountability. Oxford: Oxford University Press.

7. Freedom House, (2018). Nations in Transit 2018 Confronting Illiberalism. https://freedomhouse.org/sites/default/files/2020-

02/FH_NationsInTransit_Web_PDF_FINAL_2018_03_16.pdf

8. Högström, J. (2011). Evaluating the State of Democracy: Different Approaches and Methodologies Evaluating Political Systems: Focus on the Political Performance and the Quality of Democracy, 6th ECPR General Conference University of Iceland. Reykjavik, Iceland, 25th-27th August 2011.

9. Kaplan, R.S.; Norton D.P. (1992). The Balanced Scorecard: Measures that Drive Performance. Harvard Business Review, 70(1), p.71.

10. Kaplan, R., and Norton, D.P. (1996). Using the Balanced Scorecard as a Strategic Management System. Harvard Business Review, 74(1), p.75-85.

11. Lane, J.E. and Ersson, S. (2000). The New Institutional Politics: Performance and out comes. London and New York: Rout ledge.

12. Lane, J.E. and Ersson, S. (2002). Democratic Performance: Are There Institutional Effects? London: SAGE Publications.

13. Lijphart, A. (1999). Patterns of Democracy: Government Forms and Performance in Thirty-Six Countries. New Haven and London: Yale University Press.

14. Mochiari I. (2016). Why Half of the S\&P 500 Companies Will Be Replaced in the Next Decade, Inc. Mgaazine. https://www.inc.com/ilan-mochari/innosight-sp-500-new-companies.html

15. Official Gazette, Part I no. 310 of April 29, (2017). The total amount of amounts from private funding of political parties in 2016, according to Law no. 334/2006 on financing the activity of political parties and electoral campaigns - Social Democratic Party - PSD.

16. Official Gazette, Part I no. 371 of April 27, (2018). The total amount of amounts from private funding of political parties in 2017, according to Law no. 334/2006 on financing the activity of political parties and electoral campaigns - Social Democratic Party - PSD.

17. Official Gazette, Part I no. 328 of April 25, (2019). The total amount of amounts from private funding of political parties in 2018, according to Law no. 334/2006 on financing the activity of political parties and electoral campaigns - Social Democratic Party.

18. Official Gazette, Part I no. 305 of April 10, (2020). The total amount of amounts from private funding of political parties in 2019, according to Law no. 334/2006 on financing the activity of political parties and electoral campaigns - Social Democratic Party.

19. Powell, G. and Bingham, Jr. (1982). Contemporary Democracies: Participation, Stability and Violence. Massachusetts and London: Harvard University Press.

20. Putnam, R.D.; Leonardi, R. and Nanetti Y.R. (1993). Making Democracy Work: Civic Traditions in Modern Italy. Princeton: Princeton University Pres.

21. Popa, A. (2018). Bicameralism and referral to the chambers of Parliament. https://www.juridice.ro/581254/bicameralism-si-sesizarea-camerelor-parlamentului.html

22. Radin, B.A (2006). Challenging the performance movement Accountability, Complexity and Democratic Values. Washington: Georgetown University Press. 
23. Roller, E. (2005). The Performance of Democracies: Political Institutions and PublicPolicy. Oxford and New York: Oxford University Press.

24. The Economis Intelligence Unit Limited (2013), Why good strategies fail Lessons for the C-suit. London, New York, Hog Kong, Geneva. https://www.pmi.org//media/pmi/documents/public/pdf/learning/thought-leadership/why-good-strategiesfail-report.pdf?v=14e7a7f5-ac4c-4331-b1cf-be9e26a30d18

25. The Romanian Parliament, (2006). Act: On the financing of the activity of political parties and electoral campaigns, republished. https://www.legislationline.org/download/id/7864/file/Romania_law_financing_political_parties_as_of_20 10_en.pdf

26. The Romanian Government, (2016). Decision for the approval al the Methodological Norms for the application of Law no. 334/2016 regarding the financing of the activity of political parties and electoral campaigns, republished. Bucharest: RG .

27. The Romanian Parliament Chamber of Deputies, (2017). Legislative bulletin no. 16, June, 2017.

28. The Romanian Parliament Chamber of Deputies, (2017). Legislative bulletin no. 17, December, 2017.

29. The Romanian Parliament Chamber of Deputies, (2018). Legislative bulletin no. 18, June, 2018.

30. The Romanian Parliament Chamber of Deputies, (2018). Legislative bulletin no. 19, December, 2018.

31. The Romanian Parliament Chamber of Deputies, (2019). Legislative bulletin no. 20, June, 2019.

32. The Romanian Parliament Chamber of Deputies, (2019). Legislative bulletin no. 21, December, 2019.

33. The Romanian Parliament Senate, (2017). Legislative bulletin. Ordinary parliamentary session February - June 2017.

34. The Romanian Parliament Senate, (2017). Legislative bulletin. Ordinary parliamentary session September - December 2017.

35. The Romanian Parliament Senate, (2018). Legislative bulletin. Ordinary parliamentary session February - June 2018.

36. The Romanian Parliament Senate, (2018). Legislative bulletin. Ordinary parliamentary session September - December 2018.

37. The Romanian Parliament Senate, (2019). Legislative bulletin. Ordinary parliamentary session February - June 2019.

38. The Romanian Parliament Senate, (2019). Legislative bulletin. Ordinary parliamentary session September - December 2019.

39. User manual Software Aplication BSC Designer Light, Strategy Execution Software. https://bscdesigner.com/webbsc_manual/product-manual.pdf, Creative Commons Attribution - Non Commercial - No Derivatives 4.0 International License. 